\title{
Optimization of cone beam computed tomography for the assessment of alterations
}

\section{of the maxillary sinuses}

\section{Otimização em tomografia computadorizada para a avaliação das alterações dos seios maxilares \\ Optimización de la tomografía computarizada de haz cónico para la evaluación de alteraciones de}

los senos maxilares

Received: 08/30/2021 | Reviewed: 09/02/2021 | Accept: 09/03/2021 | Published: 09/06/2021

Bárbara Cristina Anrain

ORCID: https://orcid.org/0000-0002-7638-7112 Faculdade São Leopoldo Mandic, Brazil E-mail: barbara.anrain@hotmail.com

Ademir Franco

ORCID: https://orcid.org/0000-0002-1417-2781

University of Dundee, Dundee, Reino Unido Faculdade São Leopoldo Mandic, Brazil

E-mail: afrancodorosarioj001@ dundee.ac.br

Danieli Moura Brasil

ORCID: https://orcid.org/0000-0002-9519-4578 University of Campinas, Brazil

E-mail: danielibrasil@hotmail.com

José Luiz Cintra Junqueira

ORCID: https://orcid.org/0000-0001-6788-4021 Faculdade São Leopoldo Mandic, Brazil

E-mail: joseluiz@slmandic.edu.br

Luciana Butini de Oliveira

ORCID: https://orcid.org/0000-0002-8755-6540 Faculdade São Leopoldo Mandic, Brazil

E-mail: luciana.oliveira@slmandic.edu.br

Anne Caroline Costa Oenning

ORCID: https://orcid.org/0000-0001-9731-8629 Faculdade São Leopoldo Mandic, Brazil E-mail: anne.oenning@slmandic.edu.br

\begin{abstract}
Objective: To test the standard protocols of a CBCT unit in order to find lower-dose alternatives with diagnostically acceptable image quality for the maxillary sinuses visualization. Study design: An observational study was performed. Two dry skulls were used to simulate four conditions of the maxillary sinuses: normality, mucous retention pseudocyst, membrane thickening and bone graft. Cone beam computed tomography scans were obtained with an iCAT classic unit using different acquisition protocols and a box of polystyrene to simulate soft tissue attenuation. All the protocols were established by the manufacturer, combining different energy parameters, fields of view and voxel sizes. Multiplanar reconstructions were presented to three Oral Radiologists through blind and randomized distribution. The specialists judged general image quality, sharpness, contrast, and the presence of noise and artifacts based on a 4-points scale. Results: Protocols with higher energy parameters had significant association with higher scores for general quality, sharpness and contrast $(\mathrm{p}<0.05)$. Protocols with intermediate level of radiation dose had also significant association with good and excellent image quality; for the presence of noise and artifacts the images were rated acceptable. Conclusion: i-CAT default protocols with lower dose of radiation were able to deliver acceptable image quality for the visualization of the maxillary sinuses.
\end{abstract}

Keywords: Optimization; Radiology; Computed tomography; Maxillary sinuses.

\section{Resumo}

Objetivo: Testar protocolos padrão em tomografia computadorizada de feixe cônico (TCFC) para verificar a existência de protocolos alternativos de baixa dose e qualidade de imagem aceitável para a visualização dos seios maxilares. Metodologia: Um estudo observacional foi realizado. Dois crânios humanos foram utilizados para simular as seguintes condições: aspecto de normalidade, fenômeno de retenção de muco, o espessamento da membrana sinusal, e enxerto ósseo. Imagens de TCFC foram obtidas com o aparelho i-CAT classic utilizando diferentes protocolos de aquisição de imagem e uma caixa de poliestireno para simular a atenuação produzida pelos tecidos moles. Todos os protocolos foram preestabelecidos pelo fabricante, combinando diferentes parâmetros energéticos, campo de visão e tamanho do voxel. Reconstruções multiplanares foram apresentadas a três Cirurgiões-dentistas 
radiologistas num processo cego e randomizado. Os especialistas avaliaram a qualidade geral das imagens, sua nitidez, contraste e presença de ruídos e artefatos tendo como base uma escala de 4 níveis. Resultados: Protocolos com altos parâmetros energéticos tiveram associação significativa com valores elevados para qualidade, nitidez e contraste $(\mathrm{p}<0.05)$. Protocolos como níveis intermediários de dose de radiação tiveram associação com boa e excelente qualidade de imagem. Para a presença de ruído e artefatos, as imagens foram julgadas como aceitáveis. Conclusão: Protocolos i-CAT preestabelecidos, de baixa dose de radiação, são capazes de produzir imagens com qualidade aceitável para a visualização dos seios maxilares.

Palavras-chave: Optimização; Radiologia; Tomografia computadoriza; Seios maxilares.

\begin{abstract}
Resumen
Objetivo: Probar protocolos estándar en tomografía computarizada de haz cónico (CBCT) para verificar la existencia de protocolos alternativos de baja dosis y calidad de imagen diagnósticamente aceptable para la visualización de los senos maxilares. Metodología: Se desarrolló un estudio observacional. Se utilizaron dos cráneos humanos para condiciones similares a las siguientes: aspecto de normalidad, fenómeno de retención de moco, engrosamiento de la membrana sinusal e injerto óseo. Se obtuvieron tomografías computarizadas de haz cónico con una unidad clásica iCAT utilizando diferentes protocolos de adquisición y una caja de poliestireno para simular la atenuación de tejidos blandos. Todos los protocolos fueron establecidos por el fabricante, combinando diferentes parámetros de energía, campos de visión y tamaños de vóxel. Las reconstrucciones multiplanares se presentaron a tres radiólogos orales mediante distribución ciega y aleatorizado. Los especialistas juzgaron la calidad general de la imagen, la nitidez, el contraste y la presencia de ruido y artefactos en función de una escala de 4 puntos. Resultados: Los protocolos con parámetros de energía más altos tuvieron una asociación significativa con puntuaciones más altas para la calidad general, la nitidez y el contraste $(\mathrm{p}<0,05)$. Los protocolos con nivel intermedio de dosis de radiación también tuvieron una asociación significativa con una buena y excelente calidad de imagen; para la presencia de ruido y artefactos, las imágenes fueron calificadas como aceptables. Conclusión: los protocolos predeterminados de i-CAT con dosis más bajas de radiación fueron capaces de ofrecer una calidad de imagen aceptable para la visualización de los senos maxilares.
\end{abstract}

Palabras clave: Optimización; Radiología; Tomografía computarizada; Senos maxilares.

\title{
1. Introduction
}

In cone beam computed tomography (CBCT) images, the maxillary sinuses are visualized as hypodense structures outlined by a round hyperdense margin (Shiki et al., 2014). On the inside, the maxillary sinuses are covered by a membrane that might be visualized depending on thickness. Thickening over $2 \mathrm{~mm}$ is often hyperdense and considered pathological (Cagici et al., 2009) Other pathological condition of the maxillary sinuses is the mucous retention pseudocyst - a phenomenon that consists of the accumulation of exudate under the mucosa. Mucous retention pseudocyst is detected in CBCT images as a hyperdense, dome-shaped, hemispheric, homogeneous and well-delimited finding on the sinus floor (Bósio et al., 2009).

Both the membrane thickening and the mucous retention pseudocyst are relatively common conditions that might indicate inflammatory and allergic responses. These types of response must be diagnosed prior to maxillary sinus lift, a surgical procedure performed to increase the bone volume in the posterior region of the maxilla (Zheng et al., 2016). From a technical perspective, the surgical site is accessed via an artificial opening on the lateral wall of the sinuses. Sequentially, the sinus membrane is lifted and the space below is filled with biocompatible graft material (Sindet-Pedersen \& Enemark, 1990).

CBCT is an optimal tool for the assessment of maxillary sinus conditions and diseases (Bremke et al,. 2009). Because of the higher dose of radiation compared to panoramic radiography, however, the use of CBCT raises concern when it comes to justification and optimization (European Union, 2012). The concept of optimization corroborates the need for reducing the radiation dose maintaining, in parallel, the necessary quality for diagnostics and treatment planning (Pauwels et al., 2015). This concept follows ALARA (as low as reasonable achievable), ALADA (as low as diagnostically acceptable) (Bushberg, 2015) and ALADAIP (as low as diagnostically acceptable being indication-oriented and patient-specific) (Oenning et al., 2018) principles.

Most CBCT devices enable optimization through different settings for image acquisition. In this context, the settings should be established based on individual patient's needs and personal features (Gaêta-Araujo et al., 2020). Moreover, the 
concept of optimization from three-dimensional imaging includes radiation monitoring and updating of the specific CBCT in use (Bornstein et al., 2018). Exposure parameters are essential factors related to radiation dose, such as exposure time, tube current and tube voltage. These parameters apart, the field of view (FOV) are also an important aspect to be considered in CBCT exams, especially because its size is closely related to the radiation dose (Horner, et al. 2013). Consequently, reducing the FOV represents the utmost strategy to reduce the radiation dose (Dawood et al., 2009). It must be noted, however, that there is a relation between the selected FOV and the voxel size. Small FOVs, in general, are associated with high-resolution images (small voxel sizes) and, indirectly, a higher exposure to radiation (Scarfe et al., 2012; Kiljunen et al., 2015).

Different results/findings have been reported in the literature, depending on the criteria used to evaluate image quality, devices, exposure parameters, and the amount of dose reduction (Park et al., 2019). Considering the growing trend of CBCT exams in Dentistry, it is important to investigate alternatives to higher dose protocols for the visualization of maxillary sinuses. Based on the exposed, the present study aimed to assess the standard protocols of a CBCT unit, the i-Cat Classic, in order to find the protocol with smaller radiation dose and diagnostically acceptable images for maxillary sinuses visualization.

\section{Methodology}

\section{Study design and ethical aspects}

An observational study was designed and approved by the local committee of ethics in research (protocol: 3.271 .334 ).

\section{Sample}

Two dry skulls with well-preserved maxillae were used. The four maxillary sinuses were prepared to simulate the imaging sings of 1) membrane thickening, 2) mucous retention pseudocyst, 3) presence of bone graft, and 4) normal sinus (Figures 1 and 2).

Figure 1: Coronal view of the maxillary sinuses prepared to simulate membrane thickening (A), mucous retention (B), presence of bone graft (C) and normal sinus (D).

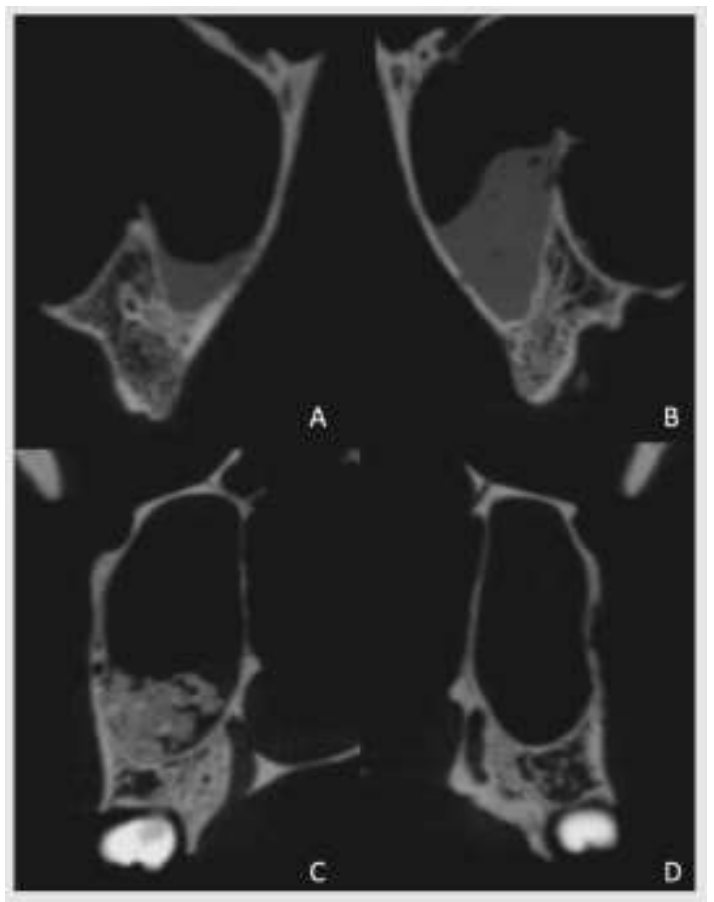

Source: Authors. 
Figure 2: Sagittal view of the maxillary sinuses prepared to simulate membrane thickening (A), mucous retention (B), presence of bone graft (C) and normal sinus (D).
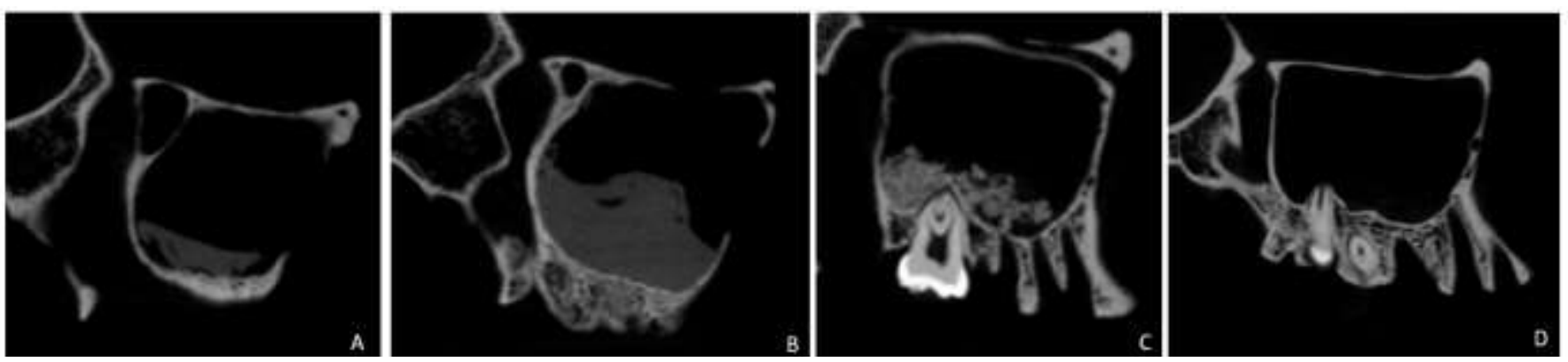

Source: Authors.

Dental wax (Lysanda, São Paulo, Brazil) was used to 1) simulate membrane thickening and 2) mucous retention pseudocyst. Using an electric dripper, the wax was positioned on the floor of the maxillary sinuses though an existing hole on the upper limit of the sinuses. Specifically for the simulation of membrane thickening, wax was positioned within a layer of $2 \mathrm{~mm}$. Mucous retention pseudocyst was simulated by adding wax up to one centimeter high (from the floor of the sinus to the apex of the 'mucous structure'). Membrane thickening and height of the mucous retention form were measured with a millimetric probe. 3) Bone graft was simulated using Bio-Oss® (Geistlich Sons Ltd., Wolhusen, Switzerland) and saline.

\section{Image acquisition}

The i-CAT Classic CBCT device (Imaging Sciences International, Hatfield, PA, USA) was used combining two FOVs $(8 \times 16 \mathrm{~cm}$ and $6 \times 16 \mathrm{~cm})$ and standard energy parameters $(\mathrm{kVp}$ and $\mathrm{mA})$ adjusted according to manufacturer protocols (Table 1). Additionally, five combinations of acquisition time and voxel size were used (10 s and $0.4 \mathrm{~mm}$ voxel size; $20 \mathrm{~s}$ and $0.4 \mathrm{~mm}$ voxel size; $20 \mathrm{~s}$ and $0.3 \mathrm{~mm}$ voxel size; $40 \mathrm{~s}$ and $0.25 \mathrm{~mm}$ voxel size; $40 \mathrm{~s}$ and $0.2 \mathrm{~mm}$ voxel size). The final study set up consisted of 10 protocols, 20 volumes acquired, and 40 maxillary sinuses scanned. Considering the stable $\mathrm{kVp}$ of the device and the changes in $\mathrm{mA}$ within the different FOVs, specific dose distribution for protocols were considered: $1<2=3<4=5$ (FOV $=8 \mathrm{~cm})$ and $6<7=8<9=10(\mathrm{FOV}=6 \mathrm{~cm})$.

In order to simulate the soft tissue of the face, the skulls were positioned inside a box of polystyrene of $2 \mathrm{~cm}$ thickness - following the instructions of Santaella et al., 2019.

Table 1: Protocols tested in the present study.

\begin{tabular}{c|ccccc} 
Protocol & FOV & Voxel & Scan time & $k V p$ & $m A s$ \\
\hline 1 & $8 \times 16 \mathrm{~cm}$ & $0.4 \mathrm{~mm}$ & $10 \mathrm{~s}$ & 120 & 9.65 \\
2 & $8 \times 16 \mathrm{~cm}$ & $0.4 \mathrm{~mm}$ & $20 \mathrm{~s}$ & 120 & 18.45 \\
3 & $8 \times 16 \mathrm{~cm}$ & $0.3 \mathrm{~mm}$ & $20 \mathrm{~s}$ & 120 & 18.45 \\
4 & $8 \times 16 \mathrm{~cm}$ & $0.25 \mathrm{~mm}$ & $40 \mathrm{~s}$ & 120 & 36.12 \\
5 & $8 \times 16 \mathrm{~cm}$ & $0.2 \mathrm{~mm}$ & $40 \mathrm{~s}$ & 120 & 36.12 \\
6 & $6 \times 16 \mathrm{~cm}$ & $0.4 \mathrm{~mm}$ & $10 \mathrm{~s}$ & 120 & 9.65 \\
7 & $6 \times 16 \mathrm{~cm}$ & $0.4 \mathrm{~mm}$ & $20 \mathrm{~s}$ & 120 & 18.45 \\
8 & $6 \times 16 \mathrm{~cm}$ & $0.3 \mathrm{~mm}$ & $20 \mathrm{~s}$ & 120 & 18.45 \\
9 & $6 \times 16 \mathrm{~cm}$ & $0.25 \mathrm{~mm}$ & $40 \mathrm{~s}$ & 120 & 36.12 \\
10 & $6 \times 16 \mathrm{~cm}$ & $0.2 \mathrm{~mm}$ & $40 \mathrm{~s}$ & 120 & 36.12 \\
\hline
\end{tabular}

FOV: field of view. Source: Authors. 


\section{Image analysis}

From the 20 volumes (40 maxillary sinuses), three reconstructions (axial, sagittal and coronal) per maxillary sinus were selected (using i-CAT own dedicated software, Xoran CAT). The total number of reconstructions reached 120. The reconstructions were exported in .tiff format and demonstrated to three Oral Radiologists. The examiners were previously trained and calibrated using CBCT ex vivo images obtained for previous studies of the lab. The training images did not belong to the original set of the study.

During the process of image analysis, the reconstructions were presented to the examiners in a 21,5" LED Full HD screen with 1920x1080 resolution (LG Corp., Seul, Korea). Each screen had 10 images randomly presented; the examiners were not aware of the used protocols. Using a progressive four-levels scale, the examiners rated the general image quality, sharpness and contrast as poor (1), moderate (2), good (3) and excellent (4). On the contrary, the level of noise and artifact were pointed-out as absent (1), low level (2), moderate level (3) and high level/ unacceptable images (4). In addition to the rating system, the examiners were requested to indicate the best and the worst image in their opinion. The technical procedure of image analysis was adapted from Brasil et al., 2019.

\section{Statistical analysis}

Data underwent descriptive statistics by means of absolute and relative frequencies. Inferential analysis consisted of Fisher's exact test with a significance of $5 \%(\alpha=0,05)$. Statistical analyses were accomplished with R Core Team $2019(\mathrm{R}$ Foundation for Statistical Computing, Vienna, Austria).

\section{Results}

Table 2 shows an overview of the images rating attributed by the observers according to the protocols, maxillary sinus condition and the assessed parameters. There was a significant association between the protocol and the general image quality in all the analyzed set ups ( $<0.05)$ (Table 2 and Figure $3 \mathrm{~A}$ ). For the maxillary sinuses with no alteration, higher quality scores were obtained for the protocols 5 and 10, while the lower scores were provided to protocols 1,2 and 6 . For the simulation of mucous retention pseudocyst higher scores were rated for the protocols 5 and 10, while the lower scores occurred for protocols 1 and 6. For the maxillary sinuses with simulated membrane thickness, higher scores also were rated for protocols 5 and 10, while the lower scores were provided to protocols 1,2,6, 7 and 8 . The condition of bone graft also found higher scores in protocols 5 and 10, and lower scores in protocols 1, 2, 3 and 4 .

Significant association also was detected for the rating of sharpness in the fours situations and in the general scenario $(\mathrm{p}<0.05)$ (Table 2 and Figure 3B). The protocols with higher sharpness were 5 and 10, while the lower scores were provided to protocols 1,6 and 8 .

The outcomes were also significant in relation to contrast (Table 2 and Figure 3C) $(\mathrm{p}<0.05)$. In general, higher scores were observed for the protocols 5 and 10, while lower scores were observed in protocols 1, 2, 3 and 6.

The analysis of the association between the presence of artifacts (acceptable quantity or not) and protocols are also presented in Table 2 and Figure 3D. For the maxillary sinuses with no alteration, there was no significant association between the quantity of artifacts and protocols $(\mathrm{p}>0.05)$. In most of the situations, the quantity of artifacts was rated acceptable. For diagnostic purposes, however, the quantity of artifacts was considered significant when associated with simulated conditions of mucous retention pseudocyst, membrane thickening and bone graft $(\mathrm{p}<0.05)$. More specifically, for the mucous retention pseudocyst and membrane thickening, protocols 1 and 6 had the lower scores related to artifacts.

Table 2 and Figure 3E also enable the visualization of a significant association between the protocol and the level of noise (acceptable or not) $(\mathrm{p}<0.05)$. In normal sinuses and in sinuses with mucous retention pseudocyst and membrane 
thickening protocols 1 and 6 had the worst scenario (images highly influenced by the noise). For the bone graft, protocols 1 and 6 were the worse.

The protocols classified as the best and the worse scenarios for image analysis are reported in Table 2. There was a significant association between the protocols and the used

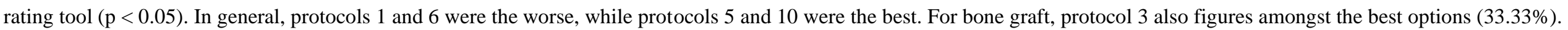

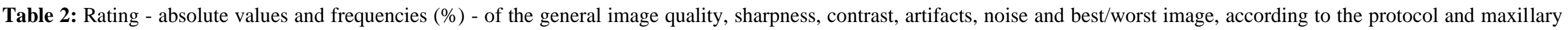
sinus condition.

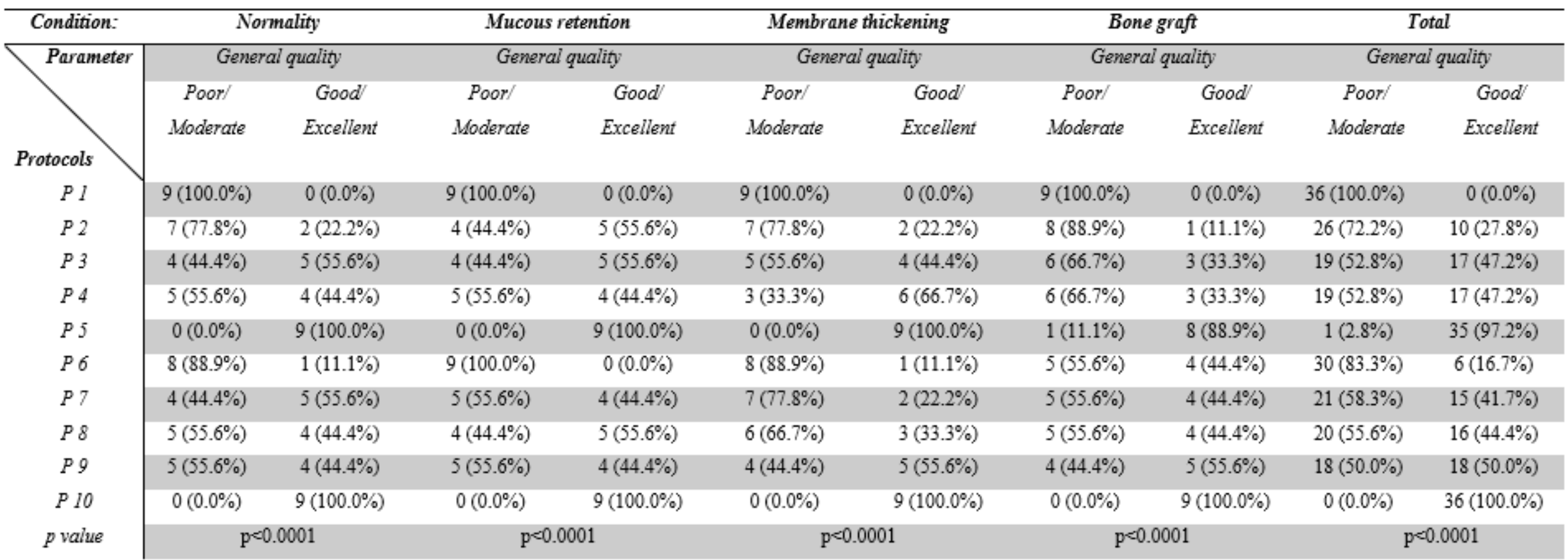

Source: Authors. 
Figure 3: Distribution of rating of the image quality (A), sharpness (B), contrast (C) artifact (D) and noise (E) as function of the protocols.

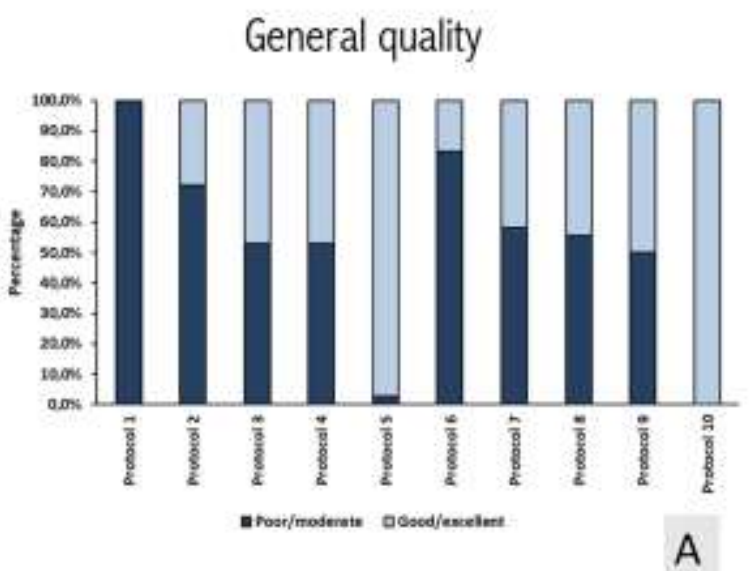

Artefacts

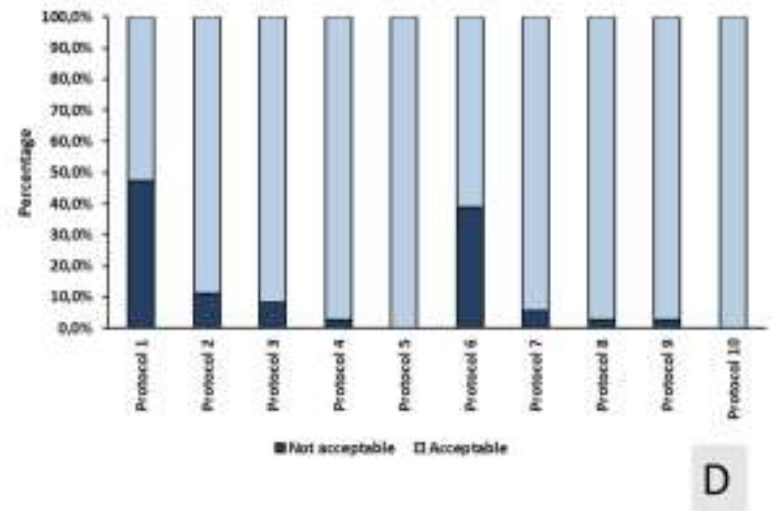

Sharpness

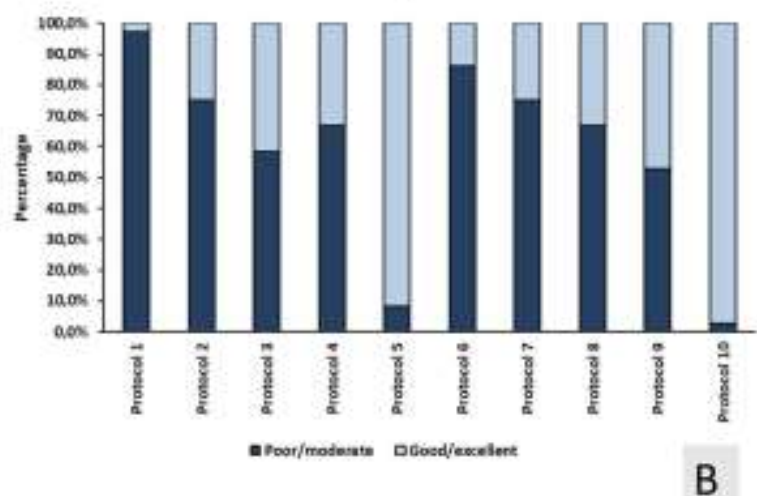

Contrast

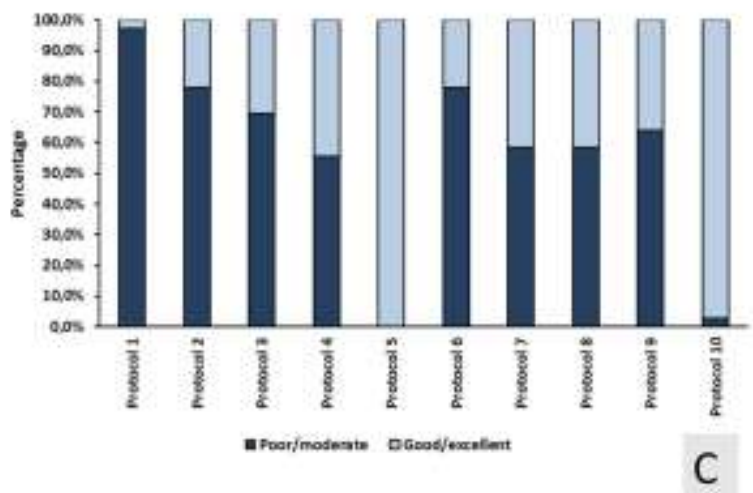

Noise

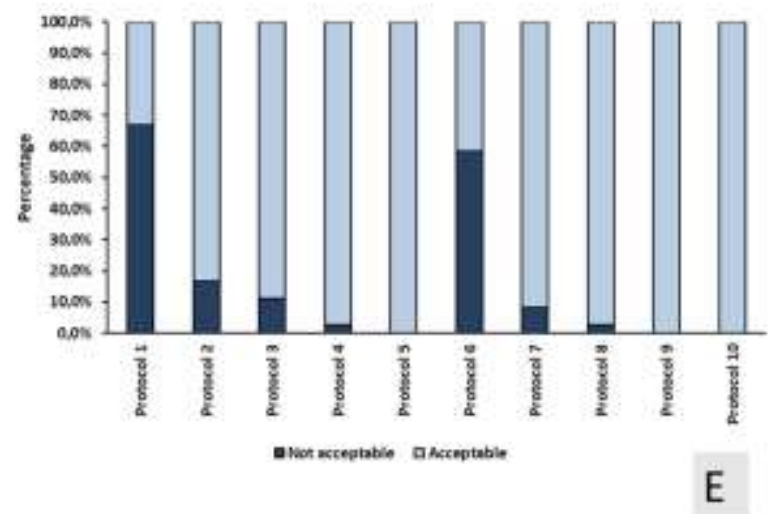

Source: Authors. 


\section{Discussion}

This study tested several CBCT protocols which the FOV encompasses the maxillary sinuses in order to find out if protocols with lower radiation dose could result in images that were diagnostically acceptable or not. The testing was performed in a maxillary sinus with no alteration, with pathological alterations and with an alteration from surgical interventions. The outcomes were expected to answer the following question: Is it possible to adjust the CBCT device with acquisition parameters that could result in acceptable images without using the manufacturer's "optimal protocol" (high-dose)? Despite the high scores of the higher dose protocols, some intermediate options emerged from the present study, namely protocols 4 and 9 - which were rated satisfactory. This finding indicates that optimization for the visualization of the maxillary sinuses is possible using the i-CAT Classic device.

Some CBCT devices offer high-dose protocols labeled as high-quality tools for the visualization of specific structures/conditions. Other devices have low-dose protocols that may rely on reduced exposure parameters or reduced number of basis images (Gaêta-Araujo et al., 2020). It must be noted that some devices have pre-established (and fixed) settings - in these devices, manual and custom adjustments are not feasible (Bornstein et al., 2018). Most manufacturers, however, enable the adjustment of energy settings ( $\mathrm{kVp}$ and $\mathrm{mA})$, stimulating the development of optimization strategies (Scarfe et al., 2012). The protocols $(n=10)$ tested in this study were part of a list of pre-established options defined by i-CAT manufacturer. Other studies designed to assess image quality as function of the device setting found out that optimization was feasible by reducing the exposure/dose below the one established by the manufacturer as default (Dawood et al., 2012; Alawaji et al., 2018).

The device used in this study was the i-CAT Classic, the first CBCT unit manufactured by Imaging Science International. More recent devices under this brand exist (i.e. iCAT Precise, Next Generation, FLX), but several Classic units are still in use worldwide. This device works with fixed $\mathrm{kVp}(120 \mathrm{kVp})$ and allows the adjustment of mA, scanning time, FOV and voxel size (Gaêta-Araujo et al., 2020). Large FOVs were used in the present study to cover the region of maxillary sinuses for full visualization. The optimization strategies of the present study consisted of FOV reduction (Pauwels et al., 2015) and mAs variation. Assuming that mAs variation has a direct and linear relation with the dose within the same FOV (increased mAs = increased effective dose) (Scarfe et al., 2012), it is possible to consider the following distribution of dose between the used protocols: $1<2=3<4=5$ (using FOV of $8 \mathrm{~cm}$ ) and $6<7=8<9=10$ (using FOV of $6 \mathrm{~cm}$ ). Protocols with the same dose $(2$ and 3, 4 and 5, 7 and 8,9 and 10) differ in relation to voxel size. Higher scores were provided to the protocols with higher resolution (small voxel size). Based on the fact that i-CAT manufacturer does not provide dose-area-product (DAP) numbers and also because dosimetric tests were not aimed in this study, the comparison between FOVs $(8 \mathrm{~cm}$ vs $6 \mathrm{~cm})$ must be interpreted carefully. Dosimetric inferences apart, the examiners rated similarly the images from different FOVs. Slightly better scores were observed in intermediate protocols with smaller FOV $(6 \mathrm{~cm})$. This outcome corroborates the need to reduce the FOV as much as possible to follow strategies in radiation protection (Horner et al., 2013).

The subjective image assessment must balance radiation dose and the necessary quality to proceed with diagnostic tasks (Oenning et al., 2018). It is known that subjective image assessment is observer-dependent. From a scientific perspective, it represents a drawback that hampers standardized comparison between studies (Liang et al., 2010). Moreover, the assessment of image quality is based on a process of visual interpretation that will dictate whether or not the image is acceptable for clinical purposes (Lofthag-Hansen et al., 2011). Based on the exposed, image quality, sharpness and contrast may be considered more subjective than the assessment of the artifact and noise levels (Brasil et al., 2019).

From an overview, membrane thickening and bone graft were the conditions with more inconsistent scores - which lacked a pattern of score increase/decrease as function of the image acquisition parameters. It may be speculated that membrane thickening and bone graft, for instance, require more image quality to enable the examiner to distinguish the anatomic limits of the sinuses and inherent alterations - especially between regions of similar image aspects, namely the 
interface of graft material and underlying bone, and between the membrane and the floor of the maxillary sinus. Mucous retention, on the other hand, is generally identified straight away because it figures as a hyperdense structure that contrasts with the hypodense aspect of the maxillary sinus (Bornstein et al., 2018).

Regarding the quantity of artifacts, the images were, in general, acceptable. Only the protocols with lowest dose were unacceptable. Intermediate protocols were especially relevant for the images with pathological alterations, because they were rated acceptable for diagnostic performance. It may be justified by the fact that mucous retention and membrane thickening, for instance, do not have high-density components (that could lead to artifact formation). The same may be interpreted for the images of bone graft, because the graft material simulates human bone - lacking higher density regions that could lead to artifacts (Tapety et al., 2004).

Intermediate protocols were also acceptable for the quantity of noise. This finding confirms once more the fact that image quality may be maintained even with the considerable reduction of the exposure parameters below the pre-established “optimal” - higher-dose - protocols (Pauwels et al., 2014; Pauwels et al., 2017).

Higher $\mathrm{mA}$ values increase the signal that reaches the detector (and the dose to the patient), consequently reducing image noise. This is the reason why setting $\mathrm{mA}$ and $\mathrm{kVp}$ remains a challenging task nowadays. The effect of changing $\mathrm{mA}$ and $\mathrm{kVp}$ - on image quality and dose - is not direct and clear in practice. Hence, it must be balanced to the point of having the best image quality possible with the lowest dose of radiation (Pauwels et al., 2014).

From the general perspective of the examiners, the protocols with the lower level of dose (1 and 6) were rated to worst, while the protocols with higher dose (5 and 10) were led to the best image quality. There is a trend of expecting that images acquired with increased exposure factors (especially energy-related ones) are more likely to be accepted by observers (Vasconcelos et al., 2014; Brasil et al., 2019). These images, however, do not necessarily figure as the best for diagnostic performances (Oenning et al., 2019).

Some limitations of the present study consist of the missing information about the DAP that could enable dosimetric inferences. Another issue to be considered is the lack of movement artifacts that were not investigated because of the original nature of the sample (dry skulls). While DAP information may be retrieved in future studies, movement artifacts may be investigated with retrospective sampling from in vivo imaging databases. Enrolling specialists from other fields (e.g. surgeons and implantodontists) is also encouraged to understand the data from different clinical perspectives. Finally, other devices (Goulston et al., 2016) must be tested and investigated regarding their own pre-established settings for image acquisition and how they can be modified in benefit of the patients and the society.

\section{Conclusion}

The outcomes of the present study indicate that optimization by balancing dose and image quality is feasible for the visualization of the maxillary sinuses (and inherent alterations) through the modification of the acquisition settings of the iCAT Classic device. Given the production of diagnostically acceptable images for the examination of the maxillary sinuses, the present outcomes follow the principle of optimization and may benefit the clinical practice with a potential reduction of radiation exposure.

\section{References}

Alawaji, Y., MacDonald, D. S., Giannelis, G., \& Ford, N. L. (2018). Optimization of cone beam computed tomography image quality in implant dentistry. Clinical and Experimental Dental Research, 4(6), 268-278. http://doi.org/10.1002/cre2.141

Bornstein, M. M., Yeung, A. W. K., Tanaka, R., von Arx, T., Jacobs, R., \& Khong, P. L. (2018). Evaluation of health or pathology of bilateral maxillary sinuses in patients referred for cone beam computed tomography using a low-dose protocol. Int J Periodontics Restorative Dent, 38(5), 699-710. http://doi.org/10.11607/prd.3435 
Bósio, J. A., Tanaka, O., Rovigatti, E., \& De Gruner, S. K. (2009). The incidence of maxillary sinus retention cysts in orthodontic patients. World J Orthod, 10(2), e7-8. PMID: 19582248

Brasil, D. M., Pauwels, R., Coucke, W., Haiter-Neto, F., \& Jacobs, R. (2019). Image quality optimization using a narrow vertical detector dental cone-beam CT. Dentomaxillofac Radiol, 48(3), 20180357. http://doi.org/10.1259/dmfr.20180357

Bremke, M., Sesterhenn, A. M., Murthum, T., Al Hail, A., Bien, S., \& Werner, J. A. (2009). Digital volume tomography (DVT) as a diagnostic modality of the anterior skull base. Acta Oto-Laryngol, 129(10), 1106-1114. http://doi.org/10.1080/00016480802620621

Bushberg, J. T. (2015). Eleventh annual Warren K. Sinclair keynote address - Science, radiation protection and NCRP: Building on the past, looking to the future. Health Phys, 108(2), 115-123. http://doi.org/10.1097/HP.0000000000000228

Cagici, C. A., Yilmazer, C., Hurcan, C., Ozer, C., \& Ozer, F. (2009). Appropriate interslice gap for screening coronal paranasal sinus tomography for mucosal thickening. Eur Arch Otorhinolaryngol, 266(4), 519-525. http://doi.org/10.1007/s00405-008-0786-6

Dawood, A., Brown, J., Sauret-Jackson, V., \& Purkayastha, S. (2012). Optimization of cone beam CT exposure for pre-surgical evaluation of the implant site. Dentomaxillofac Radiol, 41(1), 70-74. http://doi.org/10.1259/dmfr/16421849

Dawood, A., Patel, S., \& Brown, J. (2009). Cone beam CT in dental practice. Br Dent J, 207(1), 23-28. http://doi.org/10.1038/sj.bdj.2009.560

European Commission. (2012). Directorate-General for Energy. Cone beam CT for dental and maxillofacial radiology: evidence-based guidelines. Publications Office of the European Union. Accessed August 4, 2021. https://data.europa.eu/doi/10.2768/21874

Gaêta-Araujo, H., Alzoubi, T., Vasconcelos, K. F., et al. (2020). Cone beam computed tomography in dentomaxillofacial radiology: a two-decade overview. Dentomaxillofac Radiol, 49(8), 20200145. http://doi.org/10.1259/dmfr.20200145

Goulston, R., Davies, J., Horner, K., \& Murphy, F. (2016). Dose optimization by altering the operating potential and tube current exposure time product in dental cone beam CT: a systematic review. Dentomaxillofac Radiol, 45(3), 20150254. http://doi.org/10.1259/dmfr.20150254

Horner, K., Jacobs, R., \& Schulze, R. (2013). Dental CBCT equipment and performance issues. Rad Protec Dosim, 153(2), 212-218. http://doi.org/10.1093/rpd/ncs289

Kiljunen, T., Kaasalainen, T., Suomalainen, A., \& Kortesniemi, M. (2015). Dental cone beam CT: A review. Phys Med Eur J Med Phys, 31(8), 844-860. http://doi.org/10.1016/j.ejmp.2015.09.004

Liang, X., Lambrichts, I., Sun, Y., et al. (2010). A comparative evaluation of Cone Beam Computed Tomography (CBCT) and Multi-Slice CT (MSCT). Part II: On 3D model accuracy. Eur J Radiol, 75(2), 270-274. http://doi.org/10.1016/j.ejrad.2009.04.016

Lofthag-Hansen, S., Thilander-Klang, A., \& Gröndahl, K. (2011). Evaluation of subjective image quality in relation to diagnostic task for cone beam computed tomography with different fields of view. Eur J Radiol, 80(2), 483-488. http://doi.org/10.1016/j.ejrad.2010.09.018

Oenning, A. C., Jacobs, R., Pauwels, R., et al. (2018). Cone-beam CT in paediatric dentistry: DIMITRA project position statement. Pediatr Radiol, 48(3), 308316. http://doi.org/10.1007/s00247-017-4012-9

Oenning, A. C., Pauwels, R., Stratis, A., et al. (2019). Halve the dose while maintaining image quality in paediatric Cone Beam CT. Sci Rep, 9(1), 5521. http://doi.org/10.1038/s41598-019-41949-w

Park, H. N., Min, C. K., Kim, K. A., \& Koh, K. J. (2019). Optimization of exposure parameters and relationship between subjective and technical image quality in cone-beam computed tomography. Imag Sci Dent, 49(2), 139-151. http://doi.org/10.5624/isd.2019.49.2.139

Pauwels, R., Araki, K., Siewerdsen, J. H., \& Thongvigitmanee, S. S. (2015). Technical aspects of dental CBCT: state of the art. Dentomaxillofac Radiol, 44(1), 20140224. http://doi.org/10.1259/dmfr.20140224

Pauwels, R., Jacobs, R., Bogaerts, R., Bosmans, H., \& Panmekiate, S. (2017). Determination of size-specific exposure settings in dental cone-beam CT. Eur Radiol, 27(1), 279-285. http://doi.org/10.1007/s00330-016-4353-z

Pauwels, R., Silkosessak, O., Jacobs, R., Bogaerts, R., Bosmans, H., \& Panmekiate, S. (2014). A pragmatic approach to determine the optimal kVp in cone beam CT: balancing contrast-to-noise ratio and radiation dose. Dentomaxillofac Radiol, 43(5), 20140059. http://doi.org/10.1259/dmfr.20140059

Santaella, G. M., Visconti, M. A. P. G., Devito, K. L., Groppo, F. C., Haiter-Neto, F., \& Asprino, L. (2019). Evaluation of different soft tissue-simulating materials in pixel intensity values in cone beam computed tomography. Oral Surg Oral Med Oral Pathol Oral Radiol, 127(4), e102-e107. http://doi.org/10.1016/j.oooo.2018.12.015

Scarfe, W. C., Li, Z., Aboelmaaty, W., Scott, S. A., \& Farman, A. G. (2012). Maxillofacial cone beam computed tomography: essence, elements and steps to interpretation. Aust Dent J, 57(s1), 46-60. http://doi.org/10.1111/j.1834-7819.2011.01657.x

Shiki, K., Tanaka, T., Kito, S., et al. (2014). The significance of cone beam computed tomography for the visualization of anatomical variations and lesions in the maxillary sinus for patients hoping to have dental implant-supported maxillary restorations in a private dental office in Japan. Head Face Med, 10(1), 20. http://doi.org/10.1186/1746-160X-10-20

Sindet-Pedersen, S., \& Enemark, H. (1990). Reconstruction of alveolar clefts with mandibular or iliac crest bone grafts: A comparative study. J Oral Maxillofac Surg, 48(6), 554-558. http://doi.org/10.1016/S0278-2391(10)80466-5

Tapety, F. I., Amizuka, N., Uoshima, K., Nomura, S., \& Maeda, T. (2004). A histological evaluation of the involvement of Bio-Oss ${ }^{\circledR}$ in osteoblastic differentiation and matrix synthesis. Clin Oral Implant Res, 15(3), 315-324. http://doi.org/10.1111/j.1600-0501.2004.01012.x 
Research, Society and Development, v. 10, n. 11, e456101120025, 2021

(CC BY 4.0) | ISSN 2525-3409 | DOI: http://dx.doi.org/10.33448/rsd-v10i11.20025

Vasconcelos, T. V., Neves, F. S., Queiroz de Freitas, D., Campos, P. S. F., \& Watanabe, P. C. A. (2014). Influence of the milliamperage settings on cone beam computed tomography imaging for implant planning. Int J Oral Maxillofac Implants, 29(6), 1364-1368. http://doi.org/10.11607/jomi.3524

Zheng, X., Teng, M., Zhou, F., Ye, J., Li, G., \& Mo, A. (2016). Influence of maxillary sinus width on transcrestal sinus augmentation outcomes: radiographic evaluation based on cone beam CT. Clin Implant Dent Rel Res, 18(2), 292-300. http://doi.org/10.1111/cid.12298 